\title{
Growth hormone release during sleep in growth-retarded children with normal response to pharmacological tests
}

\author{
E. CACCIARI, G. COCCAGNA, A. CICOGNANI, P. PIRAZZOLI, R. GALLASSI, \\ P. FARNETI, F. BERNARDI, F. ZAPPULLA, G. GOBBI, AND P. VERUCCHI
}

From the Departments of Paediatrics, Neurology, and Anaesthesiology, University of Bologna, Italy

SUMMARY Twenty-one prepubertal children of small stature, 10 boys and 11 girls, aged from $4 \cdot 3$ to $12 \cdot 8$ years, were studied. Their height was $<3$ rd centile, and during the preceding year all had a growth rate $<4.5 \mathrm{~cm} /$ year. Arginine and L-dopa tests were given, and the release of growth hormone $(\mathrm{GH})$ during monitored sleep was investigated. On the basis of the electroencephalogram and horizontal electro-oculogram, sleep was divided into stages 1-2-3-4 and rapid-eye-movement. All the children had a $\mathrm{GH}$ response $>8 \mathrm{ng} / \mathrm{ml}$ in at least one of the two pharmacological tests, and were therefore accepted as not suffering from $\mathrm{GH}$ deficiency.

In all 21 children during sleep there was at least one secretory peak with $\mathrm{GH}>8 \mathrm{ng} / \mathrm{ml}$. Of a total of 46 secretory peaks recorded, $22(48 \%$ ) took place during deep, slow sleep (stages 3-4), $10(22 \%)$ during light sleep (stage 2), $10(22 \%$ during REM sleep, and $4(8 \%)$ during wakening. In 4 patients $(19 \%)$ no secretory peak was observed during stages $3-4$, even though there were peaks at other times.

The data (a) show that it is essential to monitor GH throughout the night to ascertain with certainty the presence or absence of physiological secretory peaks of $\mathrm{GH}$; (b) emphasise the rare disagreement between pharmacological and physiological tests; (c) suggest the use of this physiological test for GH secretion in those cases where the insulin test may be hazardous.

The secretion of some hormones, especially growth hormone $(\mathrm{GH})$ and prolactin, is closely linked to the sleep-waking cycle, and the secretion rate of $\mathrm{GH}$ is highest during sleep (Alford et al., 1973). The spontaneous release of this hormone by the pituitary in the sleeping patient and its relationship with the various stages of sleep have been the object of several studies in both the adult and child (Takahashi et al., 1968; Parker et al., 1969; Sassin et al., 1969; Illig et al., 1970; Underwood et al., 1971; Mace et al., 1972), but has been little exploited for investigating growth-retarded children (Eastman and Lazarus, 1973; Wise et al., 1975). In some cases of growth retardation a normal response to pharmacological testing has been associated with a lack of normal secretion during sleep (Eastman and Lazarus, 1973; Wise et al., 1975).

In a group of growth-retarded children we studied the pattern of $\mathrm{GH}$ secretion in relation to the various

Received 30 November 1977 stages of sleep, correlating results with plasma $\mathbf{G H}$ levels after arginine and L-dopa stimulation, and with growth rates.

\section{Materials and methods}

Twenty-one prepubertal children (10 boys, 11 girls), aged from $4 \cdot 3$ years to $12 \cdot 8$ years, were studied. Their heights were $<3$ rd centile (Tanner et al., 1966) and growth rate in the 12 months preceding the study was $<4.5 \mathrm{~cm} /$ year (mean $4.08 \pm 0.48 \mathrm{SD}$, range $2-4.5 \mathrm{~cm}$ ).

The children were in good health and receiving no treatment. Arginine and L-dopa tests were carried out by methods already described (Cicognani et al., 1975). Before and during the study of GH secretion during sleep, the children continued to lead a normal life. For blood sampling a flexible cannula was inserted into an antecubital vein 1 hour before sleep; it was connected to a plastic tube with a 3-way tap, and with a slow drip of saline. On the basis of 487 
the electroencephalogram and the horizontal electrooculogram, sleep was divided into stages (1-2-3-4) and REM (rapid-eye-movement), according to standardised criteria (Rechtschaffen and Kales, 1968).

Blood samples for $\mathrm{GH}$ were collected before sleep, on the following morning after wakening, and at various times during the night dependent on the sleep stage, but at least every 20 minutes. Samples were also taken at $10 \mathrm{am}, 2 \mathrm{pm}$, and $6 \mathrm{pm}$ on the day of the test. The children were fully informed about the details of the procedure which they accepted well. They all slept for adequate periods and had at least 3 complete sleep cycles.

Plasma GH was measured by the double-antibody radioimmunoassay method (Molinatti et al., 1969). During sleep GH peaks $>8 \mathrm{ng} / \mathrm{ml}$ were accepted as secretory. This value was chosen because in our experience peaks higher than this recorded during various pharmacological tests are indicative of normal GH release.

Statistical analysis of results was carried out with Student's $t$ test and calculating the correlation coefficient. The peak obtained during the two pharmacological tests and its relationship with the highest peak obtained during sleep was considered. The number of peaks during the night and their time in relation to the sleep stages were also evaluated. Finally, the percentage retardation of bone age in comparison with chronological age, and growth rate in $\mathrm{cm} /$ year during the 6 months preceding the study were correlated with the maximum GH peaks observed during the pharmacological tests and during sleep.

\section{Results}

All children who had a $\mathrm{GH}$ response $>8 \mathrm{ng} / \mathrm{ml}$ in at least one of the two pharmacological tests were considered as not being GH deficient (Cacciari et al., 1976). 13 of the 21 patients ( $62 \%$ ) had GH peaks $>8 \mathrm{ng} / \mathrm{ml}$ during both the pharmacological tests, the remaining 8 cases $(38 \%)$ in only one of the tests. 3 children $(14 \%)$ did not respond to the arginine test, and $5(24 \%)$ did not respond to the L-dopa test.

The mean $( \pm \mathrm{SD})$ maximum GH peak of the arginine test was $11.4 \pm 6.5 \mathrm{ng} / \mathrm{ml}$, and that of the L-dopa was $16 \cdot 2 \pm 4.6 \mathrm{ng} / \mathrm{ml}$. The mean $( \pm S D)$ plasma GH levels at $10 \mathrm{am}, 2 \mathrm{pm}$, and $6 \mathrm{pm}$ on the same day of the sleep monitoring were $1 \cdot 3 \pm 0 \cdot 8$, $2 \cdot 5 \pm 0 \cdot 6$, and $2 \cdot 0 \pm 1 \cdot 9 \mathrm{ng} / \mathrm{ml}$, respectively. The mean values obtained before the beginning of the test and after its end were $2 \cdot 1 \pm 1 \cdot 4$ and $1 \cdot 5 \pm 0 \cdot 8$ $\mathrm{ng} / \mathrm{ml}$. The difference between these plasma levels was not significant.

In all children who underwent the test there was at least one GH secretory peak during sleep. The mean maximum peak during sleep was $18 \cdot 3 \pm 6 \cdot 5$, which was higher $(P<0.025)$ than that obtained in the same group of children during the arginine test, but not significantly different from that obtained during the L-dopa test. The mean maximum peak attained during sleep in the children who had responded normally to both pharmacological tests was $19 \cdot 2 \pm 5 \cdot 6 \mathrm{ng} / \mathrm{ml}$, and it did not differ from the value $(17 \cdot 1 \pm 5 \cdot 4)$ found in the patients who had responded to only one of the two stimuli.

GH pattern during sleep is shown in the Table. Most of the secretory peaks took place during slow, deep sleep (stage 3-4) (48\%) and in the first sleep cycle $(52 \%) .20$ patients out of $21(95 \%)$ had at least one secretory peak during the first sleep cycle. During the sleep cycles following the first the secretory peaks were more uniformly distributed in all the sleep stages. Of the peaks during the waking period, two were in the phase that precedes sleep, one during the morning wakening, and one during a night wakening after a short period of sleep during which the slow deep stages of sleep were omitted. In 4 patients $(19 \%)$ no secretory peak was observed during stage 3-4, even though the peaks were present in other stages; in these cases the peak followed stage $3-4$ by $8,14,14$, and 24 minutes, respectively.

Table Total number of secretory peaks and incidence of the highest secretory peak in the different sleep stages and sleep cycles (21 subjects)

\begin{tabular}{|c|c|c|c|c|}
\hline & $\begin{array}{l}\text { Ist sleep } \\
\text { cycle }\end{array}$ & $\begin{array}{l}\text { 2nd sleep } \\
\text { cycle }\end{array}$ & $\begin{array}{l}\text { 3rd sleep } \\
\text { cycle and } \\
\text { following }\end{array}$ & Total \\
\hline $\begin{array}{l}\text { No. of secre } \\
\text { Wakening } \\
\text { Stage 1-2 } \\
\text { 3-4 } \\
\text { REM }\end{array}$ & $\begin{array}{c}\text { ory peaks } \\
3 \\
2 \\
17 \\
2\end{array}$ & $\begin{array}{l}-3 \\
3 \\
3\end{array}$ & $\begin{array}{l}1 \\
5 \\
2 \\
5\end{array}$ & $\begin{array}{c}4(8 \%) \\
10(22 \%) \\
22(48 \%) \\
10(22 \%)\end{array}$ \\
\hline Total & $24(52 \%)$ & $9(19 \%)$ & $13(28 \%)$ & 46 \\
\hline $\begin{array}{l}\text { Highest secr } \\
\text { Wakening } \\
\text { Stage 1-2 } \\
\text { REM }\end{array}$ & $\begin{array}{l}\text { tory peak } \\
\frac{1}{11} \\
1\end{array}$ & $\begin{array}{l}- \\
2 \\
1 \\
2\end{array}$ & $\frac{-}{3}$ & $\begin{array}{r}- \\
3(14 \%) \\
12(57 \%) \\
6(28 \%)\end{array}$ \\
\hline Total & $13(62 \%)$ & $5(24 \%)$ & $3(14 \%)$ & 21 \\
\hline
\end{tabular}

During the whole night the highest secretory peak occurred in most of the patients during stage 3-4 $(57 \%)$, and/or during the first sleep cycle $(62 \%)$. In 2 children the secretory peak lasted 3 hours and $2 \frac{3}{4}$ hours respectively, thus occupying more than one stage and more than one sleep cycle.

There was no correlation between the GH peak obtained during the arginine and L-dopa tests and the maximum peak obtained during sleep, nor between the GH values found during the day and the 

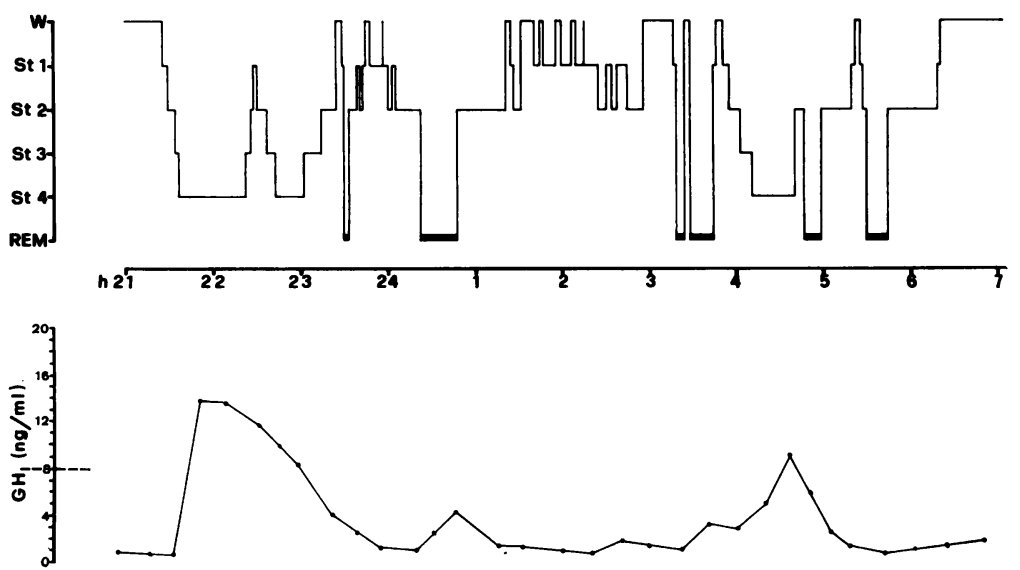

Fig. Typical pattern of $\mathrm{GH}$ secretion during 9 hours' nocturnal sleep. There are two secretory peaks, both occurring during stage 4 of sleep. The highest secretory peak occurs in the first sleep cycle. maximum peak reached during the night. Nor did the growth rate during the 6 months preceding the test, or the percentage retardation of bone age, correlate with the maximum GH peak obtained during sleep.

\section{Discussion}

This study has confirmed that sleep is an important physiological stimulus for the release of GH in children. Whereas $14 \%$ and $24 \%$ of the children examined did not respond to arginine and L-dopa respectively, during sleep there was in all the children at least one secretory peak of $\mathrm{GH}>8 \mathrm{ng} / \mathrm{ml}$, which in pharmacological tests we have found to indicate normal release of $\mathrm{GH}$; furthermore, the mean maximum peak obtained during sleep was higher than that obtained during the arginine test.

Since it has been pointed out that each individual has his own characteristic sleep rhythm and night GH release rate (Parker et al., 1969), we may suppose that the repetition of a certain endocrinological pattern influences the growth rate.

Under our experimental conditions there was no correlation between the night secretion of GH and growth rate and retardation of bone development. Nor did the tonic secretion of GH during the daytime correlate with the night secretion of the same hormone. On the other hand, none of our cases showed disagreement between the results of the pharmacological tests and the sleep test, both types of test providing evidence of normal GH release.

We consider that polygraphic monitoring of a growth-retarded child in order to collect a single blood sample at a pre-determined moment during sleep (Mace et al., 1972; Alford et al., 1973; Eastman and Lazarus, 1973; Wise et al., 1975) is not a very useful diagnostic approach. Had we adopted it, we should have had a high percentage of falsenegative results, because of the very variable night release rates of GH. In only $57 \%$ of our cases was there a peak in the first stage 3-4 of sleep (Fig.), which is generally taken as a point of reference.

In conclusion, our data (a) confirm that maximum GH release takes place during the night; (b) show that it is essential to monitor GH throughout the night to ascertain with certainty the presence or absence of physiological secretory peaks of $\mathbf{G H}$; (c) emphasise the rare disagreement between pharmacological and physiological tests for GH secretion; (d) suggest the use of this physiological test (night secretion of GH) in those cases where the insulin test may be hazardous.

\section{References}

Alford, F. P., Baker, H. W. G., and Burger, H. G. (1973). The secretion rate of human growth hormone. I. Daily secretion rates, effect of posture and sleep. Journal of Clinical Endocrinology and Metabolism, 37, 515-520.

Cacciari, E., Cicognani, A., Pirazzoli, P. Salardi, S. Mazzanti, L., Tassoni, P., Bernardi, F., Zappulla, F., and Villa, M. P. (1976). Osservazioni sulla terapia nei difetti parziali e totali di ormone dell' accrescimento. Minerva Endocrinologica, 1, 131-138.

Cicognani, A., Pirazzoli, P., Bernardi, F., Salardi, S., Zappulla, F., Zingoni, S., Tassoni, P., and Cacciari, E. (1975). Esplorazione dinamica dell' anteipofisi nel bambino. Minerva Pediatrica, 27, 837-843.

Eastman, C. J., and Lazarus, L. (1973). Growth hormone release during sleep in growth retarded children. Archives of Disease in Childhood, 48, 502-507.

Illig, R., Henrichs, I., and Sthal, M. (1970). Growth hormone release during slow-wave sleep in 38 children. (Abst.) Proceedings of the Second International Symposium on Growth Hormone, pp. 54-55. Ed. by A. Powle and E. E. Muller. International Congress Series No. 236. Excerpta Medica, Amsterdam.

Mace, J. W., Gotlin, R. W., and Beck, P. (1972). Sleep related human growth hormone (GH) release: a test of physiologic growth hormone secretion in children. Journal of Clinical Endocrinology and Metabolism, 34, 339-341. 
Molinatti, G. M., Massara, F., Pennisi, F., Scassellati, G. A., Strumia, B., and Vancheri, L. (1969). Radioimmunoassay of growth hormone. Journal of Nuclear Biology and Medicine, 13, 26-36.

Parker, D. C., Sassin, J. E., Mace, J. W., Gotlin, R. W., and Rossman, L. G. (1969). Human growth hormone release during sleep: electroencephalographic correlation. Journal of Clinical Endocrinology and Metabolism, 29, 871-874.

Rechtschaffen, A., and Kales, A. (1968). A Manual of Standardized Techniques and Scoring System for Sleep Stages of Human Subjects. U.S. National Institute of Neurological Diseases and Blindness, Neurological Information Network, Bethesda, Maryland.

Sassin, J. E., Parker, D. C., Johnson, L. C., Rosman, L. G., Mace, J. W., and Gorlin, R. W. (1969). Effect of slow wave sleep deprivation on human growth hormone release in sleep. Life Sciences, 8, Part 1, 1299-1307.

Takahashi, J., Kipnis, D. M., and Daughaday, W. H. (1968). Growth hormone secretion during sleep. Journal of Clinical Investigation, 47, 2079-2090.
Tanner, J. M., Whitehouse, R. H., and Takaishi, M. (1966). Standards from birth to maturity for height, weight, height velocity and weight velocity: British children 1965. Archives of Disease in Childhood, 41, 454-471.

Underwood, L. E., Azumi, K., Voina, S. J., and Van Wyk, J. J. (1971). Growth hormone levels during sleep in normal and growth hormone deficient children. Pediatrics, 48, 946-954.

Wise, P. H., Burnet, R. B., Geary, T. D., and Berriman, H. (1975). Selective impairment of growth hormone response to physiological stimuli. Archives of Disease in Childhood, 50, 210-214.

Correspondence to Professor E. Cacciari, Clinica Pediatrica dell'Università, Via Massarenti 11, 40138 Bologna, Italy.

The following articles will appear in future issues of this journal:

Changing concepts in asthma. A. D. Milner.

Antigen handling by the gut. W. A. Walker

At what age do bronchodilator drugs work? W. Lenney and A. D. Milner.

Congenital cytomegalovirus infection in newborn infants of mothers infected before pregnancy.

$K$. Schopfer, E. Lauber, and U. Krech.

Group B streptococci in pharyngeal aspirates at birth and the early detection of neonatal sepsis.

M. P. E. Slack and R. T. Mayon-White.

Effects of delivery by caesarean section on lung mechanics and lung volume in the human neonate. A. D. Milner, R. A. Saunders, and I. E. Hopkin.

Percutaneous catheterisation of the radial artery in newborn babies using transillumination.

R. G. Pearse. 